\title{
Development of a Multidimensional Measure of Islamic Spirituality (MMS)
}

\author{
Ms. Rabia Dasti \\ Lecturer, \\ Centre for Clinical Psychology, \\ University of the Punjab \\ E-mail: realistic_rabia@yahoo.com
}

\section{Dr Aisha Sitwat}

Assistant Professor

Centre for Clinical Psychology

University of the Punjab, Lahore

Pakistan

E-mail: sitwata786@yahoo.com

\section{Abstract}

The aim of the present study was to develop a multidimensional measure of Islamic spirituality. This research was undertaken in Pakistan. Domains of spirituality were operationalized and items were developed, followed by the evaluation of the questionnaire by religious/spiritual scholars and mental health experts. The questionnaire was administered to 813 students. After excluding items with low corrected item to total correlation in each domain («.30), a Principal Component Analysis with Oblique (Promax) rotation was conducted on 101 items. Eight clear factors were extracted: (1) Self-Discipline, (2) Quest and Search for Divinity, (3) Anger and Expansive Behavior, (4) Self Aggrandizement, (5) Feeling of Connectedness with Allah, (6) Meanness-Generosity, (7) Tolerance-Intolerance, and (8) Islamic Practices. Moderate to high internal reliability, good construct, and content validity were found. 


\section{Introduction}

Despite the fact that Islam is considered to be the second largest religion of the world, there is a dearth of empirical studies carried out on the psychology of the Muslim population (Abu-Raiya, Pargament, Stein, \& Mahoney, 2007). One reason behind the neglect of religion/spirituality in psychological research among Muslims could be the dearth of effective tools grounded in Islamic perspective (Abu-Raiya, 2010). The aim of the present research, therefore, is to investigate the theoretical construct of spirituality grounded in the Islamic worldview and to construct a sensitive, indigenous measure of spirituality in accordance with Islamic aspirations.

Zeiders \& Schaller (1998), in a review article on arguments for the inclusion of spirituality in mental health, found that there is an anti-spirituality bias in psychology and psychiatry. Their review indicates that there is a plethora of evidence which supports the notion that spirituality is a positive force in mental health. Research suggests that spirituality is not only negatively associated with symptoms of depression but also aids in its treatment (Cornah, 2006; Doolittle \& Farrell, 2004). Apart from depression, spirituality helps in coping and facilitates adjustment in the face of trauma (Peres, Moreira-Almeida, Nasello, \& Koenig, 2007). Spirituality also assists in reinterpretation of self in the face of distress and sufferings, and promotes hope, purpose and meaning in life (Cornah, 2006). Furthermore, it is found that spirituality lowers anxiety, relieves stress and enhances resilience. It also helps in forming a positive attitude toward life and leads to greater perceived social support (Pardini, Plante, Sherman, \& Stump, 2000).

The importance of spirituality in mental health has been further emphasized by the inclusion of the $\mathrm{V}$ code in the DSM-V relating to religious and spiritual problems (APA, 2013). The APA (2002) ethical principles of psychologists and code of conduct have also shed light on the importance of role of religious and spiritual issues in counseling and psychotherapy. These positive advances have led to the recognition of assessment of spirituality in the context of counseling and psychotherapy.

Spiritual assessment is an organized effort, which can help in discovering the spiritual strengths of the client and in intervention by promoting a positive holistic model of treatment (Brown, Johnson, \& Parrish, 2007). It also helps in uncovering some helpful coping resources which may be implicit in a person's religious beliefs or community (Josphenson \& Weisner, 2004). It is also believed that talking about spiritual issues in therapy helps the client in selfdiscovery (Brown, Johnson, \& Perrish, 2007).

Consequently, a large number of spiritual assessment tools have emerged over the past few years. Some of the scales of spirituality based on the Western perspective have employed theoretical model in their development such 
as Object Relation Theory as in Spiritual Assessment Inventory (Hall \& Edwards, 2002) and Fisher's model of spiritual wellbeing as in the Spiritual Wellbeing Belief Questionnaire (Gomez \& Fisher, 2003). Other scales have utilized qualitative data such as the Daily Spiritual Experience Scale (Underwood \& Teresi, 2002), the Spiritual Index of Well-Being (Frey, Daaleman, \& Peyton, 2005), the Spiritual Transcendence Index (Seidlitz et al., 2002), and the Belief and Value Scale (Hatch et al., 1998); others are based on expert opinions from religious scholars and scriptures, such as the Spiritual Involvement and Belief Scale (Hatch et al., 1998).

Furthermore with regard to Islamic spirituality, Abu-Raiya and Pargament (2010) found that most of the research conducted on Islamic spirituality/religiosity have used either a single variable to measure religiousness, or are translations or adaptation of a western tool based on Judeo-Christian spirituality, which may render their use with the Muslim population somewhat ineffective. The other tools, which have utilized a number of items and are grounded in Islamic perspective, either measure single dimension (such as religious practices or moral values) or have reported inadequate psychometric properties. For example, Francis, Sahin and Al-Failakawi (2008), and Salleh and colleagues (2000) attempted to measure the domain of Islamic morality, however these scales are based on a few items which lack the depth inherent in this domain (for example, important questions about moral dealings like pretense, spying, backbiting, and miserly behavior are missing). Dover, Miner, and Dowson (2007) and Gohar (2005) explored a similar dimension as the feeling of close bond with Allah and search for divinity. Jana-Masri and Priester (2007) attempted to measure Islamic practices, however, these measures of religiosity are not multidimensional in nature.

One of the measures of Islamic religiosity which is multidimensional in nature was developed by Abu-Raiya (2008). The Psychological Measure of Islamic Religiousness (PMIR) consists of six factors, which are Islamic Beliefs, Islamic Ethical Principles \& Universality, Islamic Religious Struggle, Islamic Religious Duty, Obligation \& Exclusivism, Islamic Positive Religious Coping \& Identification, and Punishing Allah Reappraisal. The items were generated based on literature review of Islamic construct, and found to be related to psychological health and wellbeing. In the process of item development, 25 semi-structured interviews were also conducted about religiosity with Muslims living in Israel and the United States. Although the questionnaire has reported good psychometric properties, it lacked some of the important dimensions related to Islam. Domains like self-discipline and quest and search for divinity were not addressed in the questionnaire. Moreover, the domains related to morality included only a few items, and did not encompass the richness that characterize the domain.

Kraus and colleagues (2006) developed a Muslim Religiosity Personality 
Inventory based on two facets of Islamic religiosity, Islamic worldview and religious personality. The Islamic worldview scale measures the level of agreement with the six articles of Islamic belief (i.e., belief in God, Angels, Messengers and Prophets of God, Divine Books, and Destiny). After factor analysis using oblique rotation, the Islamic worldview scale was broken down into two subscales, spiritual and worldly.

Religious Personality represents the obligatory worship, righteous works as enjoined by Islamic teachings (which is the expression of one's aqeeda (belief) in diverse situations and flows from God-consciousness and love for God). The Religious Personality subscale also measures ibadah (worship) inspired by the sense of servitude for God as well as the religiously guided behavior towards God's creatures and Islamic character (morality) stemming from Islamic traditional belief system. The Religious Personality scale was also broken down into two subscales after factor analysis, ritual and mu'amalat (commercial and civil acts or dealings under Islamic law). This measure is a representation of Islamic religiosity, but does not include important aspects like self-discipline and quest and search for divinity (the importance of which will be highlighted in the proceeding section). From the review of above scales, it can be concluded that there is no measure of Islamic spirituality sufficiently comprehensive, and there is need to address this gap in the literature.

Another challenge in the study of spirituality is that all the abovementioned measures have utilized differing definitions and conceptualizations. Currently, there is no consensus on one definition of spirituality posing a theoretical challenge in operationalizing the term (Cohen \& Koeing, 2003). Zinnbauer, Pargament, and Scott (1999), by doing content analysis of 31 definitions of religiousness and 40 definitions of spirituality, came to the conclusion that no single definition was qualified to be used as a normative definition for either of the constructs. Hence, there is no definition that can be taken as a standard. Moreover, there has been very little systematic study carried out to analyze the concept of spirituality in Islam, which may be different from other religions. For example, some of the Western conceptualizations consider religion as separate from spirituality, where spirituality is generally considered to be subjective, beneficial, and life-enhancing experience while religion is mostly viewed as institutionalized, inflexible, narrow, rigid, and dogmatic (discussion is beyond the scope of this article, for review see Hill and colleagues, 2000; and Koeing, McCullough, \& Larson 2001).

Additionally, Islamic worldview, which is thought to be important in the operationalization of the religious/spiritual construct, has unique characteristics that are different from other religions. Therefore, operationalization of the religious construct representing the unique aspects of Islamic spirituality should be studied to understand the Islamic religiospiritual philosophical framework (Krauss et al., 2005). 
The concept of spirituality/religiosity in Islam is central to the lives of many Muslims. Islamic perspective of spirituality emerges from religion. Rassool (2000) explains that in Islam there is no concept of spirituality except when seen in the light of religion, or Islamic law/shariah. Islamic law mainly is derived from the Qur'an and the prophetic traditions known as hadith (plural ahadith) and is taken as a source of guidance for Muslims in every aspect of life (Abou-Allahan, 2004). Islam, therefore, is a deen (way of life) yielding guidelines for its followers in each domain of life. It is not related to one aspect of an individual but is spread across the whole being (Iqbal, 2006).

The five pillars of Islam include, which characterizes the Islamic practices and a component related to belief are prayer, fasting, alms-giving, pilgrimage, and testimony of faith (Hamdan, 2010). These tenets are believed to include benefits for the believers; for example, it has been found that Islamic prayer can help to buffer against stress, enhance personal wellbeing, foster a sense of closeness to God, facilitate problem solving, and promote self-discipline (Henry, 2013). However, Islam emphasizes sincerity as the cornerstone for every belief and act. Belief and conduct without sincerity is metaphorically represented as a body without spirit, which is useless (Khan, 1996). Spirituality, therefore emphasizes that the purified condition of the soul (sincere devotion to God) be synchronized with the beliefs and practices. The greater the synchronization in the three aspects, the closer a person is to becoming an ideal human being (Qunawi, 1992).

The Islamic perspective of spirituality is synonymous with nearness to Allah (God) and is manifested through actions focused on seeking Divine pleasure. The strengthening of relationship with the Almighty is considered to be the driving force behind every behavior (Mawdudi, 1967). Ghazali (1909) suggested that the alchemy of happiness rests on the quest to know Allah. However, according to him mere knowledge gained through quest is not enough until it is supplemented with love of Allah, which is thought to be the fountainhead of true happiness and delight. It guides a person to gleefully organize his character, behavior and intentions according to the limits set by the law of Allah. Failure to do so can result in the maladies of soul (moral ills) which are outlined as jealousy, pride, envy, hatred and prejudice etc. Ghazali further asserts that the recollection of Allah can restructure the outer and the inner being of a person and can be a pathway to self-discipline (Ghazali, 1909).

In summary, Islamic spirituality is an implicit construct which can be measured crudely through its manifestations and expressions which, according to the above discussion, include self-discipline, God consciousness (feeling of connectedness with Allah), knowledge (quest and search for divinity), beliefs, morality, esponsibilities and obligations enjoined on every Muslim, and Islamic practices.

The present research endeavored to explore the theoretical construct 
and develop a comprehensive and multidimensional measure of Islamic Spirituality.

\section{Method}

This study was conducted in Pakistan and the items were developed in Urdu. The items have been translated into English for the purpose of this paper. This study was a multistage research project conducted in the following three phases:

1. Initial stage: Identification of the domains of Islamic spirituality, operationalization of spiritual construct, and item generation for item pool

2. Intermediary stage: Evaluation of the questions from religious/spiritual scholars and mental health professionals

3. Final stage: Pilot study, data collection, and statistical analysis

The details of each stage are outlined below.

Initial stage: Identification of the domains of Islamic spirituality, operationalization of spiritual construct, and item generation for item pool

During the first stage of the project, domains were identified and operationalized by taking into consideration electronic hadith database (http://www. searchtruth.com/) and books on sunnah (prophetic way of life) (Alvi, 1997 \& SAarfi, 1987), books on spiritual and mystical tradition of Islam (Tassawuuf) (Al-Iskandari, 2005; Ghazali, 1909; Ghazali, 1995; Ghazali, 2000; Haddad, 1989; Haddad, 2001;Mawlud, 2004;Qushayri; 1990; Qunawi, 1992; Razzaq, 1998, Al-Jilani, 1992; \& Khan, 1996) and the Holy Qur'an. Seven domains were identified which are: (1) Search for Divinity \& Meaning \& Purpose in life, (2) Belief, (3) Moral practices, (4) Self-discipline, (5) Responsibilities and Obligations, (8) Feeling of Presence/Sense of Connectedness with the Almighty Allah, and (7) Islamic Practices.

Operational definitions of the dimensions of the spiritual construct.

Search for Divinity \& meaning \& purpose in life. It is defined in terms of activities undertaken to unravel the meaning of one's existence and quest to gain understanding regarding the Ultimate Provider and Sustainer of the universe. Advice seeking from those who know, taking guidance from Qur'an and sunnah (prophetic way of life) and reflection on the objects of nature are some of 
the activities undertaken in the search for Divinity and to establish a meaning and purpose of one's life. It also includes feelings experienced in relation to the meaning and purpose of one's life. Item 'I feel an impulse to discover and know my Creator 'was included as representative of this domain.

Belief. It included all the articles of Islamic Faith like Belief in Allah, Prophet Muhammad's station as the last messenger, Day of Judgment, Angels, Destiny, previous holy texts (like the Torah and the Bible), and life after death.

Islamic practices. They are defined as performing namaz (Urdu for prayer), alms-giving, charitable acts, fasting, reciting the Holy Qur'an, and wearing hijab (for women) and attending congregational prayers (for men). Item like 'I say namaz (prayer)' was included as representative of this domain.

Moral practices. They are defined as moral values and moral ills/ailments. The moral values include truthfulness, honesty, keeping promises, courage, self-respect, generosity, steadfastness, forgiveness, patience and fairness. Moral ailments/ills include lying, becoming a false witness, hurling abuses, backbiting, suspicion and spying, making fun of others, spendthrift \& miserly behavior, show-off and pretense, exaggerated praise, greed, jealousy, love for the material world, taking revenge, haughty attitude, and pride/conceit. Items like 'I help people so that in times of need they also help me' was included as representative of this domain.

Self-discipline. It includes an organization in one's life and work, exerting self-control in daily activities like eating, sleeping, talking, and anger management. Being persistent in following one's life goals and activities is also defined in terms of self-discipline. For example, 'I am unable to follow through a wellplanned work' was included as representative of this domain.

Responsibilities and obligations. It is defined in terms of responsibilities and duties enjoined on a Muslim toward one's parents, children, spouse, close relatives, neighbors, guests, and the ordinary Muslims. Item like 'I try to help my poor relatives' was included as representative of this domain.

Feeling of presence/sense of connectedness with Allah. It is defined as feeling of an intimate, personal relationship with the Creator that imbues life with a sense of meaning, joy, and happiness. It also includes feelings of fear for Allah's wrath and accountability, hope for being forgiven for one's sins, and a belief in Allah's compassion and love. Items like, 'When I am in any difficulty I find help and assistance from Allah' were included as representative of this domain.

An item pool of 203 questions was generated representing the seven domains of Islamic spiritual construct. The Islamic references were thoroughly studied and themes were extracted in the process of their review. Common themes were then combined to form a broader category; for example, themes related to moral ills and values were combined under the heading of morality. Similarly, themes related to feelings of love, closeness, gratitude, and forgive- 
ness from Allah were combined under the heading of feeling of connectedness. This was a lengthy process in which revisions were performed repeatedly to get a final item pool.

Intermediary Stage: Evaluation of the questions from religious/ spiritual scholars and mental health professionals

The formulated questions were given to 10 religious/spiritual scholars and academics for the evaluation of the spiritual construct. The scholars/experts who evaluated the questionnaire were chosen based on the following criteria. (1) A person having a $\mathrm{PhD}$ in Islamic studies or comparative religions or is working as a mufti/aalim (religious erudite) in a recognized religious university and with a minimum teaching experience of 10 years or (2) a practicing Sufi scholar associated with an organized mystic order for at least 10 years.

Feedback session ranging from 30 minutes to an hour was taken from each evaluator to ensure a thorough understanding of the critical review that they offered. Two of the scholars who had reservations on the formulation of some of the questions were consulted repeatedly to review the amendments made in those questions.

Following are some of the suggestions that were consistent across the evaluations of Religious/Spiritual experts:

- The questions should not be formulated in a way that could induce negativity or create doubts in the mind of the examinee regarding one's faith. Moreover, the questions dealing with the sense of connectedness with Allah should particularly be framed in a positive manner. For example, questions like 'I feel that Allah is annoyed at me' were rephrased as 'I feel that Allah loves me' and 'I feel distant from Allah' was rephrased as 'I feel a close relationship with Allah'. Questions like 'I feel anger toward Allah' and 'I feel that I show ingratitude toward Allah' were omitted.

- The questions dealing with belief (articles of faith) should not be included in the questionnaire. These questions can be asked only in Yes/No format. Those endorsing No as their answer will be decreeing against the components of their faith and hence will be technically excluded from the community of believers in Islam. They will be required to pronounce shahada again, which is the proclamation of faith in one everlasting God and that Muhammad is the final Prophet in a series of prophets. Decreeing against any element of Faith when formally declared is a threat not only to the faith of the respondent but also of the person who is eliciting negativity from the respondent. This highlighted the unique sensitivity inherent in the assessment of Islamic spirituality. 
- In the domains of "search for divinity and meaning \& purpose in life", and "feeling of presence/sense of connectedness," the scale was changed from a frequency scale (Always, Often, Sometimes, Rarely, Never) to intensity scale (to a very great extent, to a great extent, to a moderate extent, to a little extent, to a very little extent). It was asserted by the scholars that the intensity of a feeling can vary but it is not possible that a Muslim, even with a minimum level of faith, will pronounce the absence of a feeling of connectedness with Allah and search for divinity and meaning and purpose in life.

174 questions were approved by the reviewers as valid indicators of spirituality, and free from the above-mentioned limitations/flaws.

The questionnaire was also given to one sociologist and three psychologists who had 10 years of teaching and research experience and have conducted research on questionnaire construction. They were asked to rate the questionnaire for its understandability and appropriateness of the questions under the domain in which they were placed as an indicator of spirituality. 157 items got the approval of the evaluators for the inclusion in the final questionnaire.

Final Stage: Pilot study, data collection, and statistical analysis

Participants. For pilot study 50 male and female students equally represented (25 from a religious university and 25 from a secular university), were recruited. Qualitative feedback was taken from students about the clarity and appropriateness of the items with the help of a questionnaire. Since changes were made in the questionnaire based on their feedback, their responses were not included in final analysis. The main study was carried out in 14 secular universities and 9 religious universities (four women's and five men's religious universities). The secular universities were coeducational, while religious universities had separate campuses for women and men. Public and private sector universities were represented in both forms of schools (secular and religious). For the main study, 980 students aged 18 years and above were recruited. However, students who reported psychological problems, those who left the questionnaires incomplete, and those who showed non-serious attitude (e.g., completed the questionnaire in 5-10 minutes) were excluded from the final analyses. Therefore, the final sample consisted of 814 students, 262 (136 males and 126 females) from religious universities and 552 (269 males, 283 females) from secular universities. The mean age of sample from mainstream universities was 20.90 years $(S D=2.41)$, while that from religious universities was 21.43 years (SD=3.03). In total, 405 males and 409 females were represented from both types of educational systems in the city of Lahore. The mean age of the participants was $21.43(\mathrm{SD}=3.03)$. The household monthly income of most 
of the participants from secular universities reflected middle socioeconomic status, while those from the religious universities belonged to a lower socioeconomic status.

\section{Instruments}

Demographic variables questionnaire. A demographic questionnaire was constructed during the present research. It included age, sex, education, and socioeconomic status.

Multidimensional Measure of Islamic Spirituality. The scale was developed during the present research and was administered on the sample. The initial questionnaire consisted of 157 items, representing six domains of spirituality operationalized in the current study: (1) search for divinity \& meaning \& purpose in life, (2) moral practices, (3) self-discipline, (4) responsibilities and obligations, (5) feeling of presence/sense of connectedness with the Almighty Allah, and (6) Islamic practices. The domains "search for divinity \& meaning \& purpose in life" and "feeling of presence/sense of connectedness with the Almighty Allah" were scored on five point intensity scale, while moral practices, self-discipline, and responsibilities \& obligations, were scored on a five-point frequency scale. The domain of Islamic practices were scored on a five-point Likert scale comprising option statements A score of 5 on any factor represented a high level of spirituality while a score of 1 corresponds to a low level of spirituality. Each factor gives a separate score and a high correlation of each domain with other domains would represent a high level of spirituality. Hence, a spiritual person would score consistently higher on each subscale. The items of the subscales were mixed up together before administering it on the participants.

\section{Procedure}

The present study was presented to the University of the Punjab's Departmental Doctoral Program Committee for approval. The study was then carried out on the university students in the city of Lahore. After getting permissions for assessment from the vice chancellors of the universities and informed consent from the students, the questionnaire was administered. The administrationtook place in a classroom setting with groups ranging from 10 to 60 students. The final version of the spirituality questionnaire, along with the demographic variable questionnaire and feedback form, was administered. Out of the nine religious universities that were contacted for data collection, only one refused while none of the secular universities refused data collection. The overall refusal rate was found to be $10.1 \%$, which is deemed to be acceptable. In view of 
the length of the questionnaire, the refusal rate of $10.1 \%$ is consistent with the previous studies (for example, Sitwat (2005) reported a 12\% refusal rate).

Statistical analyses. Descriptive statistics were used to compute means and frequencies for the demographic variables. Item and factor analysis was carried out as a data reduction process and to explore the factor structure of the spiritual construct. Internal reliability of each scale was also calculated using reliability analysis. Pearson product moment correlation analysis was conducted to calculate the test-retest reliability of the factors.

\section{Results}

Item, factor and reliability analysis

Corrected item-to-total correlation analysis was performed for each dimension operationalized of the multidimensional scale. Items with low corrected item-to-total correlation of the hypothesized dimension were deleted (Neterneyer, Bearden, \& Sharma, 2003). A value of .30 or less of the corrected itemcorrelation was taken as a criterion for deleting items (Field, 2009). In total 56 items were deleted before the final factor analysis.

A Principal Component Analysis (PCA) of remaining 101 items was done with Promax (Oblique) rotation. Factor analysis with eight factors with suppression of .40 was undertaken (because of this suppression, 26 items did not load on any factors). The eight factor solution resulted in a more thematically sound solution and explained $37.18 \%$ of variance (for details see Table 1 ).

\section{Reliability}

Internal consistency: After factor analysis, Cronbach's alpha was computed for each subscale of the final questionnaire. This analysis revealed moderate to high (.68 to .84) internal consistency for each domain of the questionnaire (see Table 1 for details).

Test-retest reliability: Test-retest reliability was established by readministering the questionnaire after 15 days of the initial administration on 50 students ( 25 from secular universities and 25 from religious universities). The results indicated significant high correlation between the scores of each scale with its readministered scores (see Table 2 for details). 
TABLE 1. Factor wise arrangement of the Factor Loadings for Exploratory Factor Analysis with Promax (Oblique) Rotation of the items of Multidimensional Measure of Islamic Spirituality Scales (English Translation)

\begin{tabular}{|c|c|c|c|c|c|c|c|c|c|}
\hline & & SD & Q & $A \& E$ & SA & FC & $M-G$ & $T-I$ & IP \\
\hline 1 & $\begin{array}{l}\text { *I am unable to follow through a well- } \\
\text { planned work }\end{array}$ & .695 & .064 & -.105 & -.084 & .013 & -.103 & -.122 & .033 \\
\hline 2 & $\begin{array}{l}\text { *I am unable to complete the work I set up } \\
\text { for }\end{array}$ & .661 & -.090 & .034 & -.012 & .099 & .090 & -.155 & -.044 \\
\hline 3 & $\begin{array}{l}\text { *I feel sluggish in taking initiative in any } \\
\text { work }\end{array}$ & .598 & .083 & .057 & -.098 & -.061 & -.045 & .038 & .008 \\
\hline 4 & $\begin{array}{l}\text { *I find it hard to complete any responsibility } \\
\text { that is entrusted to me }\end{array}$ & .591 & .092 & .130 & .017 & -.011 & .065 & -.161 & -.046 \\
\hline 5 & $\begin{array}{l}\text { *I feel that despite exerting effort I am un- } \\
\text { able to keep my things in order }\end{array}$ & .540 & -.138 & .096 & -.115 & .008 & -.052 & .022 & .051 \\
\hline 6 & $\begin{array}{l}\text { *I become indecisive if people are not in } \\
\text { agreement with my plans }\end{array}$ & -.537 & -.020 & .087 & -.183 & -.054 & -.009 & .040 & .159 \\
\hline 7 & $\begin{array}{l}\text { lity of my work is not in accord to } \\
\text { tial }\end{array}$ & .520 & -.105 & -.033 & .018 & .031 & .011 & -.121 & .047 \\
\hline 8 & $\begin{array}{l}\text { disapproval from other people I } \\
\text { o follow a righteous act }\end{array}$ & .497 & .090 & -.078 & .188 & .061 & .128 & -.053 & -.161 \\
\hline 9 & & .479 & .006 & .043 & -.104 & & -.098 & & .157 \\
\hline 10 & *I d & .42 & .033 & .042 & .001 & -.0 & -.054 & -.044 & .087 \\
\hline 11 & $\begin{array}{l}\mathrm{g} \text { in which } \\
\mathrm{mpt}\end{array}$ & .405 & .106 & -.082 & .160 & -.009 & .175 & .055 & -.195 \\
\hline 12 & *la & .400 & .002 & .162 & -.034 & & .223 & & -.121 \\
\hline 13 & In 0 & -.028 & .742 & .120 & .099 & & .019 & -.021 & -.283 \\
\hline 14 & $\begin{array}{l}\text { In ord } \\
\text { plate }\end{array}$ & -.001 & .652 & .155 & -.003 & .092 & .010 & .017 & -.256 \\
\hline 15 & $\begin{array}{l}\text { I feel an impulse to discover and know my } \\
\text { Creator }\end{array}$ & .014 & .625 & -.028 & .111 & .050 & .018 & -.121 & .024 \\
\hline 16 & $\begin{array}{l}\text { I try to find out whether the prevailing cul- } \\
\text { tural traditions are in accordance to Islam }\end{array}$ & .073 & .621 & -.029 & .014 & .054 & .000 & -.061 & -.115 \\
\hline 17 & $\begin{array}{l}\text { In order to form a bond with Allah, I take } \\
\text { assistance from Qur'anic Ayat (Verses) and } \\
\text { Sunnah (prophetic way of life) }\end{array}$ & -.019 & .585 & .092 & .136 & .082 & -.009 & .070 & .051 \\
\hline 18 & $\begin{array}{l}\text { In order to form a bond with Allah, I take } \\
\text { help from scholars and religious/spiritual } \\
\text { guides }\end{array}$ & -.006 & .568 & -.271 & .109 & -.105 & .073 & .033 & .170 \\
\hline 19 & & .04 & .562 & -.115 & -.00 & & -.031 & & -.119 \\
\hline 20 & $\begin{array}{l}\text { I try to take assistance from Qur'an and Sun- } \\
\text { nah (prophetic way of life) in every aspect } \\
\text { of life }\end{array}$ & .134 & .526 & -.042 & .023 & .259 & -.092 & .037 & .187 \\
\hline 21 & $\begin{array}{l}\text { One of the priority in my life is to know about } \\
\text { myself }\end{array}$ & .097 & .486 & -.014 & -.100 & .204 & -.018 & -.131 & -.103 \\
\hline 22 & $\begin{array}{l}\text { I feel that the purpose of my life is to form a } \\
\text { bond with Allah }\end{array}$ & -.109 & .485 & .075 & .108 & .164 & .088 & -.079 & .158 \\
\hline 23 & $\begin{array}{l}\text { In order to form a bond with Allah, I ex- } \\
\text { change my ideas with my teachers / friends }\end{array}$ & -.070 & .474 & -.228 & .025 & -.096 & .061 & .123 & .158 \\
\hline 24 & $\begin{array}{l}\text { In order to form a bond with Allah, I attend } \\
\text { religious gatherings }\end{array}$ & -.037 & .424 & -.265 & .197 & -.009 & .036 & .098 & .323 \\
\hline 25 & *When I am angry I swear & .015 & -.106 & .603 & -.021 & .104 & -.100 & . 181 & .168 \\
\hline 26 & *When I swear, my anger dissipates & .048 & -.120 & .532 & -.016 & .082 & .047 & .263 & .035 \\
\hline 27 & *If I don’t have money, I take a loan to buy & .030 & -.061 & .527 & .067 & -.001 & .133 & -.169 & -.034 \\
\hline
\end{tabular}
things I like 
28 *When I am with my friends, I make fun of $\quad-.023 \quad .016$ others

$29 *$ enjoy making fun of others

$-.175-.025$

$\begin{array}{llll}30 & * \text { When I have money, I buy things that I really } & .069 & .025\end{array}$ don't need at that time

31 * l like to gossip

$.046 \quad .099$

.519

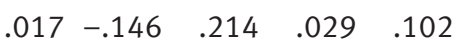

32 *If someone wrongs me then I take greater

$-.183-.060$

.498

$\begin{array}{lllll}.037 & -.012 & .071 & .056 & .099\end{array}$ revenge from him/her

33 *When I am among my friends, I can't resist talking about the negative aspects of somebody who is not present there

34 * I want to see myself at a social position so that people respect me

$35 *$ I wish to get all those things which make me appear unique

36 * I want to see myself at a financial position so that people respect me

37 *l like doing things which earn me praise

38 * think that if I have latest/new things with me, then I am an important and successful person

$39{ }^{*} \mathrm{~A}$ lot of shopping makes me feel happy

$$
.107-.019
$$

.477

$\begin{array}{lllll}.263 & -.129 & -.089 & -.101 & .135\end{array}$

.476

$\begin{array}{lllll}.085 & -.154 & .026 & .040 & .076\end{array}$

$\begin{array}{llllll}.443 & .066 & -.028 & .122 & .408 & .025\end{array}$

.412

$\begin{array}{lllll}.034 & .096 & .052 & -.027 & -.042\end{array}$

$\begin{array}{lll}.045 & .089 & -.111\end{array}$

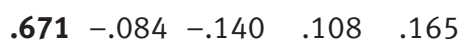

$\begin{array}{lll}-.051 & .081 & .083\end{array}$

$\begin{array}{lllll}.651 & -.045 & -.142 & .046 & .022\end{array}$

$\begin{array}{lll}-.035 & .084 & -.100\end{array}$

$\begin{array}{lllll}.648 & -.052 & .029 & .040 & .199\end{array}$

$\begin{array}{lll}.052 & .091 & .031\end{array}$

$\begin{array}{lllll}.606 & -.098 & -.105 & .053 & .053\end{array}$

$.010-.050 \quad .112$

$\begin{array}{llllll}.526 & .114 & -.004 & -.008 & -.082\end{array}$

$40 *$ I help people so that in times of need they

$\begin{array}{lll}-.115 & .184 & .281\end{array}$

$.049 \quad .081-.021$

$\begin{array}{llllll}.512 & -.091 & -.096 & -.001 & .047\end{array}$ also help me

$41 *$ If I see something new/latest, I feel an urge $\quad \begin{array}{llll}-.003 & .042 & .321\end{array}$ to get it immediately

42 *I feel that because of my qualities I am bet- $\quad-.047 \quad-.052 \quad .086$ ter than most of the people

43 *I don't find anything wrong in praising someone a little more than deserved if it helps me in getting my work done

44 When I pray, I feel that Allah is listening to my prayer

45 I am proud to be a Muslim

$\begin{array}{lll}.025 & .026 \quad .298\end{array}$

$\begin{array}{lllll}.465 & -.129 & .157 & .002 & -.132\end{array}$

$.459-.028-.126 \quad .008-.034$

$\begin{array}{lllll}.433 & .000 & -.047 & .050 & .149\end{array}$

$\begin{array}{lllll}.397 & -.054 & .093 & -.052 \quad .043\end{array}$

46 When I am in any difficulty, I find help and assistance from Allah

47 I am hopeful that despite all my wrongdoing, Allah will forgive me

48 I feel that Allah is conversing with me through Qur'anic Ayat (Verses)

49 I can feel the love of Allah

50 I can feel that Allah is observing all my acts

51 I can feel the fear of Allah in my heart

$$
.102-.037-.016-.086
$$

$\begin{array}{llll}.660 & -.087 & .018 & .171\end{array}$

$\begin{array}{llll}-.063-.084 & .068-.016\end{array}$

$\begin{array}{llll}.632 & .060 & -.146 \quad .175\end{array}$

$\begin{array}{llll}-.010 & -.042 & .020 & -.031\end{array}$

$\begin{array}{llll}.613 \quad .02 & -.097 \quad .094\end{array}$

$.113-.043-.086-.059$

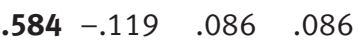

$\begin{array}{llll}.054 \quad .266 & -.164 \quad .006\end{array}$

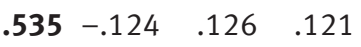

$\begin{array}{llll}-.015 \quad .166 & -.060-.083\end{array}$

$.516-.028-.011-.014$

$\begin{array}{lllll}-.039 & .0152 & .080 & -.086\end{array}$

$\begin{array}{lllll}.509 & .077 & -.021 & .008\end{array}$

$\begin{array}{llll}-.020 & .036-.005-.046\end{array}$

$\begin{array}{lllll}.501 & .060 & .031 & -.049\end{array}$

52 When I have to face any difficulty, I think it

.037

$.226-.010-.051$

$.501-.106 \quad .166-.118$

as a source from Allah for the strengthening of my faith

53 The feeling of Allah's love has brought favorable change in my daily life

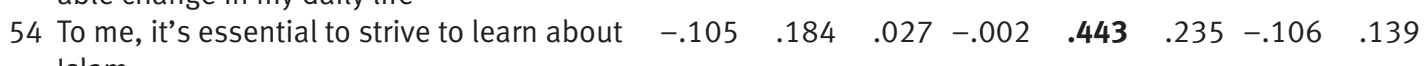
Islam

55 I feel that the search for truth is possible

56 If there is a fight between my relatives/

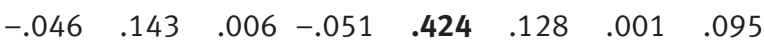
friends, I try to resolve it

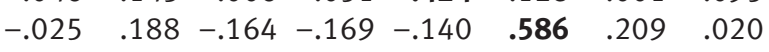

$\begin{array}{llllllllll}57 & \text { I convey my knowledge to others so that they } & .009 & .101 & .003 & -.130 & -.029 & .547 & .062 & .020\end{array}$ can also benefit from it 
58 *If I have knowledge about anything, I don't tell others because if I do they might excel past me

$59 *$ * feel hesitance in meeting my poor relatives $\quad \begin{array}{llllllll}.027 & -.055 & .127 & .100 & .039 & \mathbf{. 5 0 0} & -.046 & -.055\end{array}$

60 I try to help my parents in every possible way $\begin{array}{llllllll}-.123 & .098 & .224 & -.120 & .020 & .498 & .029 & -.009\end{array}$

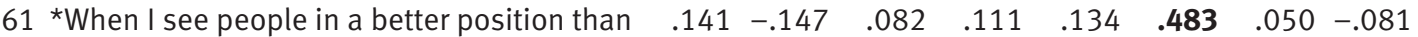
myself, my heart aches

62 I try to help my poor relatives

$$
\begin{array}{rrrrrrrr}
-.031 & .262 & -.127 & -.162 & -.071 & .462 & .152 & .008 \\
-.043 & .308 & .213 & -.073 & -.139 & .456 & .059 & -.12 \\
.089 & -.057 & .002 & .245 & -.020 & .441 & -.033 & -.126 \\
& & & & & & & \\
-.031 & -.064 & -.047 & .072 & .013 & .058 & .703 & -.061 \\
& & & & & & & \\
-.115 & -.092 & -.022 & .142 & .011 & .047 & .635 & .00 \\
& & & & & & & \\
-.189 & .084 & .108 & -.141 & -.048 & .143 & .616 & -.029 \\
-.112 & -.054 & .382 & .000 & .088 & .022 & .575 & -.108 \\
& & & & & & & \\
.150 & .074 & -.007 & .105 & -.096 & .005 & .489 & -.094
\end{array}
$$

63 I like for others what I like for myself help others

65 *I don't like meeting people with whom I have disagreements

$66{ }^{*}$ I stop meeting people with whom I have serious disagreements

67 I forgive people who have wronged me

68 *I don't feel at rest until I have avenged the wrong done to me

69 *An unpleasant feeling persists if I don't have courage to avenge the person who wronged me

$70 *$ k keep on thinking on how to avenge the person who wronged me

71 *While angry, I lose control over myself control

72 I say Namaz

73 I recite Qur'an

74 I do $Z i k r$

75 I fast

$$
\begin{array}{llllllll}
-.051 & -.044 & .014 & .0142 & .043 & .016 & .484 & -.013
\end{array}
$$

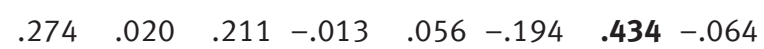$$
\begin{array}{llllllll}
-.019 & -.120 & .134 & .107 & .158 & -.053 & -.012 & .762
\end{array}
$$$$
\begin{array}{llllllll}
.087 & -.095 & .0117 & .054 & .099 & -.017 & -.070 & .733
\end{array}
$$$$
\begin{array}{llllllll}
-.006 & -.043 & .040 & .067 & .168 & -.069 & -.008 & .613
\end{array}
$$

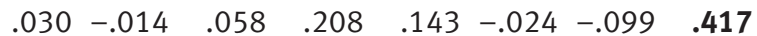

Eiganvalue

$\%$ of Variance

$\begin{array}{llllllll}15.446 & 6.656 & 3.923 & 3.247 & 2.357 & 2.104 & 1.916 & 1.845\end{array}$

Alpha

$\begin{array}{lllllllll}15.293 & 6.590 & 3.884 & 3.215 & 2.333 & 2.083 & 1.897 & 1.826\end{array}$

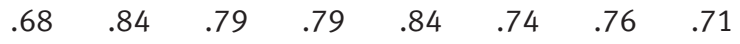

Note. Factor loadings greater than .40, SD =Self Discipline, $\mathrm{Q}=$ Quest and Search for Divinity, A \& $\mathrm{E}=$ Anger \& Expansive Behavior, $\mathrm{SA}=$ Self-Aggrandizement, $\mathrm{FC}=$ Feeling of Connectedness with Allah. $\mathrm{M}-\mathrm{G}=$ Meanness-Generosity, $\mathrm{TI}=\mathrm{Tolerance}-$ Intolerance, $\mathrm{IP}=$ Islamic Practices.

*Represents items which needs to be reverse scored

The items were originally in Urdu language and have been translated into English for the purpose of this publication

Table 2 Pearson Product Moment Correlation between test and retest scores on subscales of a Multidimensional Measure of Islamic Spirituality Subscales.

\begin{tabular}{ll}
\hline Variable & $r$ \\
\hline 1.SD & $0.886^{* \star}$ \\
2.Q & $0.956^{\star \star}$ \\
3.A\&E & $0.854^{* \star}$ \\
4.SA & $0.863^{\star \star}$ \\
5.FC & $0.847^{\star \star}$ \\
6.M-G & $0.808^{\star \star}$ \\
7.TI & $0.742^{\star \star}$ \\
8.IP & $0.793^{\star *}$
\end{tabular}

Note. $\mathrm{SD}=$ Self Discipline, $\mathrm{Q}=$ Quest and Search for Divinity, $\mathrm{A} \& \mathrm{E}=$ Anger \& Expansive Behavior, SA = Self-Aggrandizement, $\mathrm{FC}=$ Feeling of Connectedness with Allah. $\mathrm{M}-\mathrm{G}=$ Meanness-Generosity, $\mathrm{TI}=$ Tolerance-Intolerance, $\mathrm{IP}=$ Islamic Practices.

$$
\star \star=p<.01
$$




\section{Validity}

Construct and Content validity. Content and construct validity was established through carefully defining the conceptual framework of Islamic Spirituality, by reviewing relevant Islamic and Western literature, and seeking the opinion of experts of the field. The review of the questionnaire by 10 experts endorsed its content as indicative of Islamic Spirituality. The experts also agreed that the questionnaire extensively measures the intended domain.

The questionnaire was further given to two psychologists and a sociologist for its psychometric evaluation. The psychologists suggested that three questions from Islamic Practices subscale (Hijab, Attending Congregational Prayers, and Zakat) should be discarded due to difficulty in scoring. They approved the remaining 157 questions for the pilot study. After factor analysis the questionnaire was again given to two psychologists and a sociologist to confirm if the theme of each domain represented the items that are placed under its heading. The experts approved the thematic structure of the domains.

\section{Discussion}

The current study affirmed the Multidimensionality of the Spiritual construct. Eight factors were extracted, comprising 75 items. Although a 75 -item questionnaire is often considered to be long in clinical context or research, AbuRaiya, Pargament, Stein, and Mahoney (2007) indicated that Islamic religiosity is a broad perspective comprising of many indices, and some people follow some aspects while others adhere to different aspects. Indices comprising few simplistic items do not sufficiently measure the construct adequately. Therefore, an extensive measure is required to serve the purpose.

Self-Discipline, which is considered an important dimension of Islamic spiritual literature (Ghazali, 1909; Mawlud, 2004) emerged as an independent and unique factor of the present study. Islam asserts that the life of a man is the capital which he utilizes for attaining everlasting felicity. This everlasting felicity can only be achieved if an individual structures a daily routine and spends time in purposeful activities. The steadfastness, persistence, and self-control help achieve glory in this world and the hereafter as well. Thus, it is a continuous fight against the baser instincts of the human, and helps one achieve objectives. In addition, it also calls for Allah's approval, as Allah loves those noble acts which are performed on regular basis, irrespective of how meager they are.

Quest and Search for Divinity and Feeling of Connectedness with Allah also emerged as two separate factors. The Islamic literature is pregnant with importance of Quest and Search for Divinity. According to Al-Jilani (1992), the very purpose of the creation of the universe is to discover the attributes of Allah in the signs of Allah. Therefore the quest to strive to know the Truth 
and Reality is inherent in every individual. Allah can be known in this material world through His attributes manifested in His creation. The more closely one gets to know and see through the light of the names of divine attributes, the greater ascendance one experiences in one's Spiritual quest. Only when one transcends into the region of Allah's intimacy does one is able to see in the ultimate realm of the manifestation of Allah's essence, the unity of the absolute (Al-Jilani, 1992). In essence the quest is a struggle that leads a person closer to the Almighty Allah. A Muslim in this world is always in the search for a greater reality, and strives to develop greater intimacy with Allah.

Dover, Miner, and Dowson (2007) also attempted to measure a similar construct like quest and search for divinity, however, they aimed to study religious openness and maturity through their scale, and only included a few items related to the sources for reflection outlined in the Holy Qur'an (e.g., features like reflection on the objects of universe, and seeking guidance from religious authorities for religious matters were missing). Gohar's (2005) scale attempted to measure knowledge/learning dimensions, but the researcher utilized fewer items to measure a broader domain. The present study, therefore, attempts to utilize a comprehensive definition of quest and search for divinity and feeling of connectedness with Allah, taking directives from the Qur'an and sunnah.

The items relating to the domains of morality and responsibilities and obligations were split up and factor analysis presented them under four factors which were named according to their themes as Anger and Expansive Behavior, Self-Aggrandizement, Meanness-Generosity, and Tolerance-Intolerance. In the present research, domain of "responsibilities and obligations," which was operationalized as a separate domain, was subsumed in the four factors relating to moral dealings (ills and values). Therefore, the present research highlights that the enjoined responsibilities and obligations are in fact a reflection of Islamic morality. Future research can help in determining if these two domains are reflective of each other or can be studied as two separate domains.

Francis, Sahin, and Al-Failakawi (2008), Abu-Raiya (2008), and Salleh and colleagues, (2000) attempted to measure the domain of Islamic morality in their researches. However, they assessed morality through fewer items, which didn't encompass the many other aspects of moral dealings.

Islamic Practices were also measured by other researchers and are consistent with the items of present research (Abu-Raiya, 2008; Jana-Masri \& Priester, 2007). Only a few items are included in the present research and more items relating to Islamic practices can be included in the future research. The item relating to almsgiving/charity was not loaded by the factor analysis. This might be because majority of the student population were dependent on their caregivers and were unemployed. However, in future researches this question may be pertinent for a broader community population.

One of the most important findings of this research was the rewording 
suggested by the religious/spiritual scholars of some of the negatively worded items (see method section for details) and the exclusion of items relating to belief. Their opinion has opened a new perspective on faith-related studies. The study conducted by Williamson and Ahmad (2007) also shed light on how some questions are found offensive and thought to be detrimental to faith by imams. A well-noted point in the article suggests that, for a Muslim, all knowledge is secondary to the Qur'an. Since the researcher gathered the opinions of 10 experienced religious scholars and a majority emphasized this point, changes were made to respect the sensitivity inherent in the construct. One of the ways to integrate religion in psychology is to work in collaboration with the religious scholarly community and in a country like Pakistan, where pathways leading to mental health are frequently directed through religious authorities, such collaboration becomes even more essential.

One of the problems that can arise in incorporating the suggestions of the religious/spiritual scholars was from the psychometric perspective i.e. individuals might give bias responses to the positively framed questions. However, there is evidence which supports that most people do not give bias responses when participating in volunteer in studies or in clinical contexts (McCrae\& Costa, 1983b as cited in McCrae\& Costa, 2010). Moreover, a social desirability scale can be used in the future researches to determine if there is any response bias threatening the validity of the questions.

\section{Limitations and Suggestions}

Since the research was conducted in Pakistan, caution should be maintained in generalizing the results to other countries. Cross-cultural research in the future may help to generalize the results of the study.

The female researcher was not allowed to monitor the data collection in some of the religious institutes for males. In such situations detailed instructions were given to the teacher carrying out the data collection. Since no difficulty in understanding the questions and their content was reported throughout the study, the data is thought of as genuine and representative of the student population. However, to take a more precautionary approach in future research, male assistants can be trained for data collection.

Some of the important questions, like ones regarding Hajj and modest dress enjoined on Muslims, were not included in this study. However, in future research these questions can easily be added in the questionnaire.

\section{Implications}

This was the first step of long-term research project which aims to ascertain the relationship between mental health and Islamic spirituality. The next step 
will be to determine the convergent and divergent validity of the questionnaire with different measures like self-esteem, life-satisfaction, and other scales of religiosity, and by including different populations (e.g., community population, patients with mental illnesses, and professionals belonging to different fields).

\section{References}

Aarfi, A. (1987). Uswa e rasool e akram (The ways of the Prophet Muhammad). Karachi, Pakistan: Idarah-e-Islamiyah.

Abou-Allaban, Y. (2004). Muslims. In Josephson, A. M., \& Peteet, J. R., (Eds.), Handbook of spirituality and worldview in clinical practice. (pp. 111-124). Washington: American Psychiatric Publishing, Inc.

Abu-Raiya, H. (2008). A psychological measure of Islamic religiousness: Evidence for relevance, reliability and validity. The International Journal for the Psychology of Religion. 18(4), 291-315. doi: 10.1080/10508610802229270

Abu-Raiya, H., \& Pargament, K. I. (2010). Empirically based psychology of Islam: Summary and critique of the literature. Mental Health, Religion \& Culture, 14(2), 93-115. Retrieved from http://dx.doi.org/10.1080/13674670903426482

Abu-Raiya, H., Pargament, K. I., Stein, C., \& Mahoney, A. (2007). Lessons learned and challenges faced in developing the psychological measure of Islamic religiousness. Journal of Muslim Mental Health, 2(2), 133-154. doi:10.1080/15564900701613058

Al-Iskandari, I. A. (2005). The book of illumination. (Kugle, S. Trans.) Louisville, KY: Fons Vitae.

Al-Jilani, A. A. (1992).The secret of secrets: The manifestation of lights. (Bayrak, T. Trans). Cambridge, UK: Islamic Texts Society.

Alvi, K. (1997). Insan-e-kamil. Lahore, Pakistan: Al-Faisal Publishers.

American Psychological Association. (2002). Ethical principles of psychologists and code of conduct. American Psychologist, 57, 1060-1073. http://dx.doi. org/10.1037/0003-066X.57.12.1060

American Psychological Association (APA). (2013). Diagnostic and statistical manual of mental disorders (DSM V) ( $5^{\text {th }}$ ed.). Washington DC: American Psychiatric Publishing.

Aw'an, M. A. (2001). Asrar at tanzil: Holy Quran, translation and commentary: Vol. 3. (Irfan, A., Trans.) Pakistan: Idarah-e-NaqshbandiahOwaisiah, Dar ul-Irfan.

Brown, D. R., Johnson, E. P., \& Parrish, M. S. (2007). Spirituality assessments: Limitations and recommendations. Retrieved from http://counselingoutfitters.com/ vistas/vistas07/ Brown.htm

Cohen, A. B., \& Koenig, H. G. (2003). Religion, religiosity and spirituality in the biopsychosocial model of health and ageing. Ageing International, 28(3), 215-241. doi:10.1007/s12126-002-1005-1

Cornah, D. (2006). The impact of spirituality on mental health: A review of the literature. London: Mental Health Foundation.

Doolittle, B. R., \& Farrell, M. (2004). The association between spirituality and depression in an urban clinic. Journal of Clinical Psychiatry, 6(3), 114-118.

Dover, H., Miner, M., \& Dowson, M. (2007). The nature and structure of Muslim Religious Reflection. Journal of Muslim Mental Health, 2(2) 189-210. doi:10.1080/15564900701614858 
Field, A. (2009). Discovering statistics using SPSS (3 ${ }^{\text {rd }}$ ed.). Washington, DC : Sage.

Francis, L. J., Sahin, A., \& Al-Failakawi, F. (2008). Psychometric properties of two Islamic measures among young adults in Kuwait: The Sahin-Francis Scale of Attitude toward Islam and the Sahin Index of Islamic Moral Values. Journal of Muslim Mental Health, 3, 9-24. doi: 10.1080/15564900802035201

Frey, B. B., Daaleman, T. P., \& Peyton, V. (2005). Measuring a dimension of spirituality for health research: Validity of the Spirituality Index of Well-Being. Research on Aging, 27(5), 556-577. doi: 10.1177/0164027505277847

Ghazali, A. (1909). The alchemy of happiness. (Field, C. Trans.). London: Northbook Society.

Ghazali, A. (1995). The revival of the religious sciences. (Winter, T. J. Trans.). Cambridge: The Islamic Texts Society.

Ghazali, A. (2000). Deliverance from error. (McCarthy, J. R. Trans.). Louisville, KY: Fons Vitae.

Gohar, M. (2005). Development of an indigenous spiritual wellness inventory for Pakistani youth.(Unpublished Masters thesis), National Institute of Psychology, Quaide-Azam University, Islamabad, Pakistan.

Ghorbani, N., Watson, P. J., \& Khan, Z. H. (2007). Theory and practice, theoretical, empirical, and potential ideological dimensions of using western conceptualizations to measure Muslim religious commitments. Journal of Muslim Mental Health, 2(2), 113-131. http://dx.doi.org/10.1080/15564900701613041

Gomez, R., \& Fisher, J. W. (2003). Domains of spiritual well-being and development and validation of the Spiritual Well-Being Questionnaire. Personality and Individual Differences, 35(8), 1975-1991. http://dx.doi.org/10.1016/S0191-8869(03)00045-X

Haddad, A. A. (2001). Knowledge and wisdom. (Badawi, M. Trans.). Chicago: Starlatch Press.

Haddad, A. A. (1989). The book of assistance (Badawi, M. Trans.). London: Quilliam Press.

Hall, T. W., \& Edwards, K. J. (2002). The Spiritual Assessment Inventory: A theistic model and measure for assessing spiritual development. Journal for the Scientific Study of Religion, 41(2), 341-357. http://dx.doi.org/10.1111/1468-5906.00121

Hatch, R. L., Burg, M. A., Naberhaus, D. S., \& Hellmich, L. K. (1998). The Spiritual Involvement and Beliefs Scale: Development and testing of a new instrument. Journal of Family Practice, 46, 476-486.

Hill, P. C., Pargament, K. I., Hood, R. W., Jr., McCullough, M. E., Swyers, J. P., Larson, D. B., \& Zinnbauer, B. J. (2000). Conceptualizing religion and spirituality: Points of commonality, points of departure. Journal for the Theory of Social Behaviour, 30, 51-77. http://dx.doi.org/10.1111/1468-5914.00119

Iqbal, M. (2006). Knowledge and religious experience. In Sheikh, M. S. (Ed.), The reconstruction of religious thought in Islam (pp.1-22). Lahore, Pakistan: Institute of Islamic Culture.

Jana-Masri, A., \& Priester, P. E. (2007). The development and validation of a Qur'an-based instrument to assess Islamic religiosity: The religiosity of Islam scale. Journal of Muslim Mental Health, 2(2), 177-188. http://dx.doi. org/10.1080/15564900701624436

Josephson, A. M, \& Peteet, J. R. (2004). Worldview in psychiatric assessment. In Josephson, A. M., \& Peteet, J. R., (Eds.), Handbook of spirituality and worldview in clinical practice. (pp. 15-30). Washington, DC: American Psychiatric Publishing. 
Josephson, A. M, \& Wiesner, I. S. (2004). Worldview in psychiatric assessment. In Josephson, A.M., \& Peteet, J. R. (Eds.). Handbook of spirituality and worldview in clinical practice. (pp. 31-46). Washington, DC: American Psychiatric Publishing.

Khan, A. Y. (1996). Dalael us-Suluk (Talha, A, Trans.). Pakistan: Idarah-e-Naqshbandiah Owaisiah, Dar ul-Irfan.

King, M., Speck, P., \& Thomas, A. (2001). The Royal Free Interview for Spiritual and Religious Beliefs: Development and validation of a self-report version. Psychological Medicine, 31, 1015-1023. http://dx.doi.org/10.1017/S0033291701004160

Koenig, H. G., McCullough, M. E., \& Larson, D. B. (2001). Handbook of religion and health. New York: Oxford University Press.

Krauss, S. E., Hamzah, A. H., Suandi, T., Noah, S.M., Juhari. R.,Manap. J. H., et al (2006). Exploring Regional Differences in Religiosity among Muslim Youth in Malaysia. Review of Religious Research, 47(3) 238-252.

Krauss, S. E., Hamzah, A., Juhari, R., \& Hamid, J. (2005). The Muslim ReligiosityPersonality Measurement Inventory (MRPI): Towards understanding the differences in the Islamic religiosity among Malaysian Youth. PertanikaJournal of Social Sciences \&Humanities, 13(2), 173-186.

McCrae, R. R., \& Costa, P. T., Jr. (2010). NEO ${ }^{\mathrm{TM}}$ Inventories for the NEO ${ }^{\mathrm{TM}}$ Personality Inventory-3 (NEO $\left.{ }^{\mathrm{TM}}-\mathrm{PI}-3\right)$, Five Factor Inventory-3 (NEO $\left.{ }^{\mathrm{TM}}-\mathrm{FFI}-3\right)$, Personality Inventory-Revised (NEO-PI-R ${ }^{\mathrm{TM}}$ ): professional manual. USA: PAR.

Mawdudi, S. A. (1967). The Islamic way of life. (Ahmad, K., \& Murad, K. Trans.). Pakistan: Islamic Foundation.

Mawlud, M. (2004). Purification of the hearts. (Yousaf, H. Trans.). Chicago: Starlatch.

Neterneyer, R. G., Bearden, W.O., \& Sharma, S. (2003). Scaling procedures: issues and applications. London: Sage.

Pardini, D. A., Plante, T. G., Sherman, A., \& Stump, J. E. (2000). Religious faith and spirituality in substance abuse recovery: Determining the mental health benefits. Journal of Substance Abuse Treatment, 19(4), 347-354. http://dx.doi.org/10.1016/ S0740-5472(00)00125-2

Peres, J. F. P., Moreira-Almeida, A., Nasello, A. G., \& Koenig, H. G. (2007). Spirituality and resilience in trauma victims. Journal of Religion and Health, 46, 343-350. http://dx.doi.org/10.1007/s10943-006-9103-0

Qunawi, N. D. (1992). Faith and practices of Islam: Three thirteen-century Sufi texts. (Chittick, W. C. Trans.). Albany: State University of New York Press.

Qushayri, A. Q. (1990). The principles of Sufism. (Schlegell, B. Trans.) Berkeley, CA: Mizan Press.

Razzaq, A. (1998). Tasawwufbaraay intermediate (Tasawwuf for Intermediate). Pakistan: Idarah-e-NaqshbandiahOwaisiah, Dar ul-Irfan.

Rassool, G. H. (2000). The crescent and Islam: healing, nursing and the spiritual dimension: Some considerations towards an understanding of the Islamic perspectives on caring. Journal of Advanced Nursing. 32(6), 1476-84. http://dx.doi. org/10.1046/j.1365-2648.2000.01614.x

Salleh, H. M. Hatta S. M., Nor. I. M., Shamsuddin. K., Kassim. K., ,Ismail. R., et al. (2000). Hatta Islamic Religiosity Scale 1996 (HIRS96): A reliability and validity study. Malaysian Journal of Psychiatry, 8(1), 5-14.

Sitwat, A. (2005). Minor psychiatric symptomatology, life events, social support, religion and coping: A study of Pakistani Muslim women immigrants in Britain. (Unpublished doctoral thesis), Royal Holloway University of the London: U.K. 
Sharma, P., Charak, R., \& Sharma,V. (2009). Contemporary perspectives on spirituality and mental health. Indian Journal of Psychological Medicine, 31(1), 16-23. http:// dx.doi.org/10.4103/0253-7176.53310

Seidlitz, L., Abernethy, A. D., Duberstein, P. R., Evinger, J. S., Chang, T. H., \& Lewis, B. L. (2002). Development of the spiritual transcendence index. Journal for the Scientific Study of Religion, 41(3), 439-453. http://dx.doi.org/10.1111/1468-5906.00129

Turbott, J. (1996). Religion, spirituality and psychiatry: Conceptual, cultural and personal challenges. Australian and New Zealand Journal of Psychiatry, 30, 720-727. http://dx.doi.org/10.3109/00048679609065037

Williamson, P., \& Ahmad, A. (2007). Survey research and Islamic fundamentalism: A question about validity. Journal of Muslim Mental Health, 2(2),155-176. doi: $10.1080 / 15564900701614809$

Underwood, L. G., \& Teresi, J. A. (2002). The Daily Spiritual Experience Scale: Development, theoretical description, reliability, exploratory factor analysis, and preliminary construct validity using health-related data. Annals of Behavioral Medicine, 24(1), 22-33. http://dx.doi.org/10.1207/S15324796ABM2401_04

Zeiders, C. L., \& Schaller, J. L. (1998). The argument for the inclusion of spirituality. The Journal of Christian Healing, 20(1), 33-45.

Zinnbauer, B. J., Pargament, K. I., \& Scott, A. B. (1999). The emerging meanings of religiousness and spirituality: Problems and prospects. Journal of Personality, 67, 889-919. http://dx.doi.org/10.1111/1467-6494.00077 